\title{
Acid Corrosion Inhibition of 1018 Carbon Steel by Using Mentha Spicata
}

\author{
A. Rodríguez-Torres ${ }^{1}$, M.G. Valladares-Cisneros ${ }^{2}$, V.M. Salinas-Bravo ${ }^{3}$, J.G. Gonzalez-Rodriguez, ${ }^{1, *}$ \\ ${ }^{1}$ Universidad Autónoma del Estado de Morelos, Centro de Investigaciones en Ingeniería y Ciencias \\ Aplicadas, Ave. Universidad 1001, Chamilpa, C.P. 62209, Cuernavaca, Morelos, México. \\ ${ }^{2}$ Universidad Autónoma del Estado de Morelos, Facultad de Ciencias Químicas e Ingeniería, Ave. \\ Universidad 1001, Chamilpa, C.P. 62209, Cuernavaca, Morelos, México. \\ ${ }^{3}$ Instituto Nacional de Electricidad y Energias Limpias, Av. Reforma 108, Temixco, Mor., Mexico. \\ *E-mail: ggonzalez@uaem.mx
}

doi: $10.20964 / 2017.06 .20$

Received: 24 February 2017 / Accepted: 28 March 2017 / Published: 12 May 2017

A study on the use of Mentha spicata (M. spicata) as eco-friendly inhibitor for the corrosion of 1018 carbon steel in sulfuric acid was performed with the use of potentiodynamic polarization curves and electrochemical impedance spectroscopy (EIS) measurements at 25,40 and $60{ }^{0} \mathrm{C}$. Results have shown that M. spicata is a good, mixed type of corrosion inhibitor. An increase in its efficiency was observed when both its concentration and elapsing time increased, but when the temperature increased, its efficiency decreased. M. spicata contains several compounds which contain heteroatoms in their structure, which are chemically adsorbed on to the steel surface by following a Frumkin type of adsorption isotherm, forming protective corrosion products.

Keywords: Acid corrosion, carbon steel, green inhibitor.

\section{FULL TEXT}

(C) 2017 The Authors. Published by ESG (www.electrochemsci.org). This article is an open access article distributed under the terms and conditions of the Creative Commons Attribution license (http://creativecommons.org/licenses/by/4.0/). 